\title{
Application of Geophysical Method to Delineate Kaolin Deposit at Kankara, Northwestern Nigeria
}

\author{
Joseph O. Osumeje ${ }^{1}$ Eshimiakhe Daniel ${ }^{2}$ and Kolawole M. Lawal ${ }^{3}$
}

1,2,3 Department of Physics, Ahmadu Bello University, Nigeria.

Email: josumejeh@yahoo.com

\begin{abstract}
Area around Kankara Local Government Area of Katsina State, which lies within the Northern Nigerian Basement complex, is considered as one of the most prospective regions for Kaolin mineralization in Nigeria. A geophysical survey involving aeromagnetic and electrical resistivity survey was employed to delineate the fault and features that may be related to the mineralization. The aeromagnetic map results which included the first and second vertical derivatives and analytical signal map, revealed that a continuous linear feature trends Northwest to Southeast direction and Northeast to Southwest direction with a few traces along East-West and North-South. The electrical resistivity tomography was taken at a mining site along which the fault line passes through. It revealed that the Kaolin mineral lies within the overburden and weathered layer, with depth approximately 10-15m, extending from East-West.
\end{abstract}

Keywords: Aeromagnetic map, ERT, fault-line, Kaolin, Mineralization,

\section{INTRODUCTION}

Natural minerals have been the most important foundation to every economic and industrial development in any nation. Nigeria is an African nation richly blessed with mineral resources such as petroleum and various solid minerals which include Kaolin, coal and bitumen (Obaje, 2009). Non-metallic rocks and minerals which include gnesis, marble, granite and limestone occur in large amounts in many parts of Nigeria. They are being used as part of raw materials for both industrial and infrastructural development, which drastically reduces the level of importation of such raw materials.

Mining has for several years sustained the economy of nations of the world, serving as a valuable means of export and a major contributor to the GDP of these nations. For instance, South Africa, a country rich with mineral resources and with an established mining structures, generated over R351 billion from mining in the year 2018 (Wagner and Wellmer, (2008)). Nigeria's mining sector is very much untapped and underdeveloped (Olade, (2019)), and the illegal (artisan) mining activities have been a conduit through which some of these natural resources are been smuggled out of this country rather than create manufacturing industries for the benefit of the country (Olade, (2019). Due to weak regulations and lots of artisan mining, only about 5.3 billion naira was recorded from mining in 2019, while substantial quantities of both gold and Kaolin, to mention but a few, worth hundreds of millions of dollars extracted by artisanal mining are being smuggled out of the country with loss of revenue. With more than 15 billion deposits of bitumen, 3 billion metric tons of iron 
ore, 10 million deposits of lead-zinc and many other valuable minerals resources, Nigeria is sitting on resources that can drastically change its economic course (Olade, (2019)). The change in prices and demand of these minerals has encouraged artisanal mining activities and these has dominated all the local activities in this region. Due to the level of poverties, the local indigenous youths become self-employed with little monies and knowledge, go into fields and gather distinct stone and minerals from the earth surface or from shallow depths to sell to interested buyer as against the state laws. The activities of such people have led to environmental pollutions and contamination of soil which has caused poisoning in states in Nigeria (Anka, et al., (2020), Nwabueze, (2018) Environmental Law Institute, (ELI) (2014)).

To the best of my knowledge, there are no previous geophysical works on this site, but however some authors have work in other fields on Kaolin in and around Kankara. Ajayi and Adefila (2012) and Christian et al., (2018) have both shown that Kaolin exists in Kankara from their works. While, Hussaini et al., (2016), used the Wenner-Schlumberger electrode configuration an electrical resistivity method that is sensitive to both horizontal and vertical structures to delineate Kaolin deposit at Dajin Gwamna in Kastina state. Their results uncovered the following layers; top soil layer, weathered basement layer and fresh basement layer, with the resistivity of from 41 to 97 for the Kaoin in this area. The Kaolin layer thickness was determined to be $1.25 \mathrm{~m}$ up to $39.4 \mathrm{~m}$ and is believed to extend beyond the study area.

Elsewhere, Akinlalu, et al., (2018), carried out a subsurface structural study of the mineralization potential of Ilesa schist belt SW Nigeria using aeromagnetic data. They were able to use Euler deconvolution and Spectral Analysis method to determine the depth to structures and the magnetic source. Also, the orientations of lineaments are predominantly Northeast - Southwest trending with a few trending East - West axis. The delineated structures are believed to be host to the target minerals because the artisan mining activities are very prominent in the area. Badmus and Olatinsu (2009), carried chemical analysis on samples and used Vertical Electrical Sounding (VES) method to carry out the evaluation of Kaolin deposit in Southwest Nigeria. They were able to map as few as three geoelectric layers and as much as five geoelectric layers of which the topsoil is mainly clayey sand (sandy clay), a weathered layer of Kaolin clay and sandstone, then the fresh basement. The Kaolin clay (with resistivity between $1099 \Omega \mathrm{m}$ to $22037 \Omega \mathrm{m}$ ) and thicknesses between $0.4-17$ $\mathrm{m}$ was identified in most $(80 \%)$ of the VES stations. The chemical analysis shows that the Kaolin clay was made up of high Alkaline metal concentration and is acidic in nature.

In other to investigate more accurately and delineate the subsurface structures that the Kankara Kaolin, is located, an integrated geophysical method that is sensitive to the Kaolin mineral is used. The susceptibility and resistivity of Kaolin and its host rock can easily be differentiated by these two methods, hence the need to use the aeromagnetic data and the electrical resistivity imaging.

The purpose of aeromagnetic survey in mineral exploration varies from surface delineation of lineaments to subsurface identifications of structures like dyke, silt, folds, intrusions and contacts. These structures are known to play important roles in the housing of mineral types. The techniques that can be used to identify this structures are as follows; theta derivative, tilt derivative (TDR), Normal Standard Derivative (NSTD), Horizontal Gradient Magnitude (HGM) and directional filter, (Wijns et al., 2005; Cooper and Cowan, 2008; Miller and Singh, 1994; Cordell and Grauch, 1985; Cooper, 2003). On the other hand, electrical resistivity imaging (tomography) can provide details about fracturing and weathering of a section along a profile. The saturation of the subsurface can influence (positive or negative) the 
relative resistivity of the subsurface as compared to a fresh (undisturbed) basement rock mass (Jongmas and Garambois, 2007; Meric et al., 2005; Lebourg et al., 2005).

\section{The Study Area and its Geology}

The study area, which is a Kaolin mining site, is located in Kankara Local Government of Katsina state, Northwest of Nigeria. The area lies within the Northwestern Nigerian Basement complex and is confined within the latitudes $11^{\circ} 53^{\prime} 28^{\prime \prime} \mathrm{N}-11^{\circ} 53^{\prime} 43^{\prime \prime} \mathrm{N}$ and longitudes $7^{\circ} 26^{\prime} 21^{\prime \prime} \mathrm{E}-7^{\circ} 00^{\prime} 00^{\prime \prime} \mathrm{E}$ (Figure 1). The entire study area is made up of rocks types of the Basement complex, some of which includes; biotite gneiss, granites gneiss, migmatites, with some meta-sediments of granitic rocks of the older granites suite and amphibolite facies metamorphism, (Ajibade, 1976). The area considered in this report is underlain by mica schist, dipping generally SE at angles varying from $27^{\circ}$ to $43^{\circ}$ (Hussaini et al., (2016)). The geological structures in this study area generally trend east-west with outcrops that host Mic-schist identified along valley channels. The in situ rocks appear as silvery to light grey at undisturbed surfaces, they can also be embedded with quatzo feldspathic veins in between fracture planes. Beyond the mica - schist, the surrounding areas are occupied by biotite - granite - gneiss. A ridge of foliated weathered pegmatite with the foliation direction parallel to the local strike is found in the southern part of the survey area. The rock has low SE angle of dip varying between $22^{\circ}$ and $40^{\circ}$ (Oyeka, 1976). The study area is also located in the emplacement that occur from the Lower Proterozoic to the Upper Palaeozoic era of North Western Nigeria, which is characterized by series of discontinuous ridge of granite and gneiss as inselbergs in the western part, this makes the terrain a very rugged landscape, with nearly rolling to flat surface towards the southern part. Geological classification of evidences on the field including the samples of mica schist, it can be inferred that the meta-sediments in the study area are metamorphosed greywacke shale sequence (Kankara and Farouk, 2015).

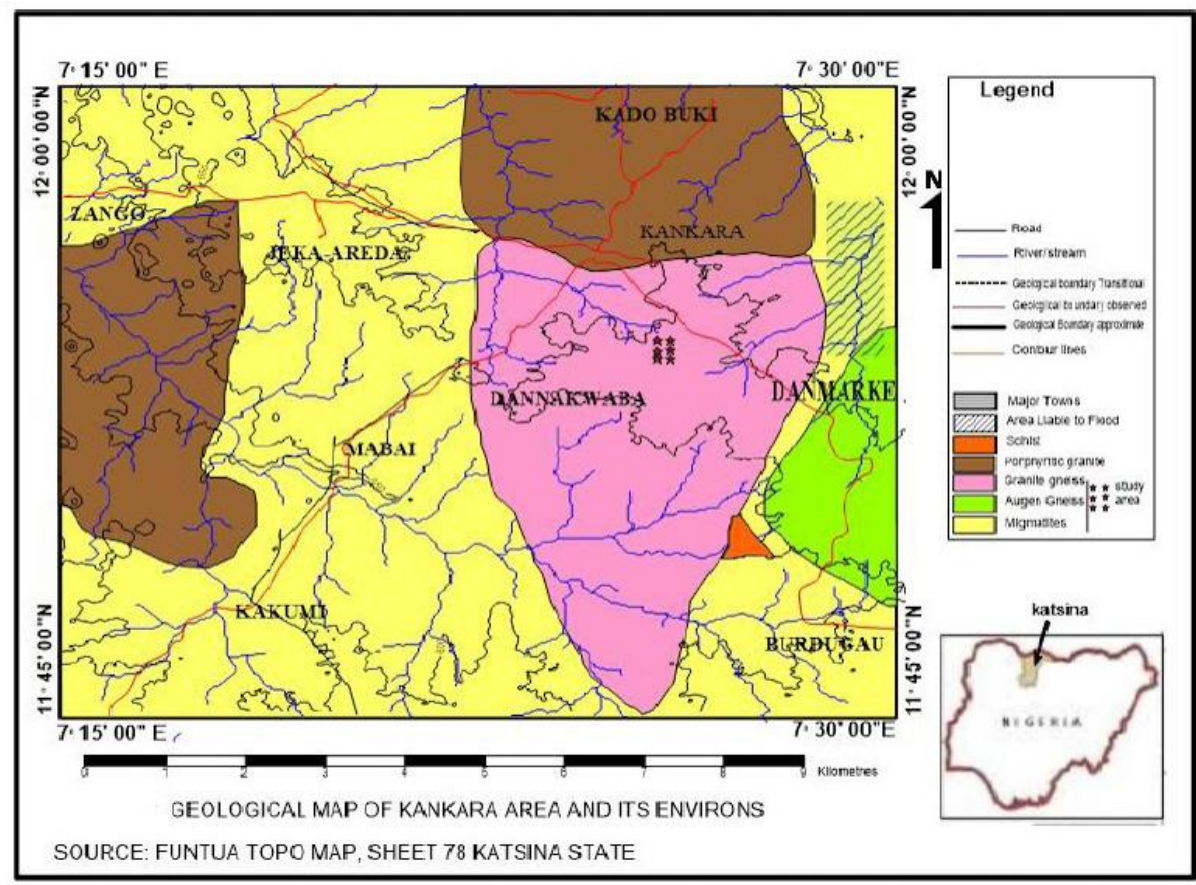

Figure 1: The location and geological map of the area of study (Source: Kankara and Farouk, 2015)

\section{METHODOLOGY}

The aeromagnetic data used was purchased the Nigerian Geological Survey Agency (NGSA). The flight line for the survey was spaced $500 \mathrm{~m}$ parallel and oriented Northeast Southwest direction and at an average height of $80 \mathrm{~m}$ above ground level. By using the 
OASIS Montaj software, the data was corrected and then a total aeromagnetic intensity map (TMI) was generated. To correct for the placement of the anomaly above its causative body, a reduction to magnetic pole was carried out and is shown in Figure 2 below from which further enhancement techniques can be used for interpretation.

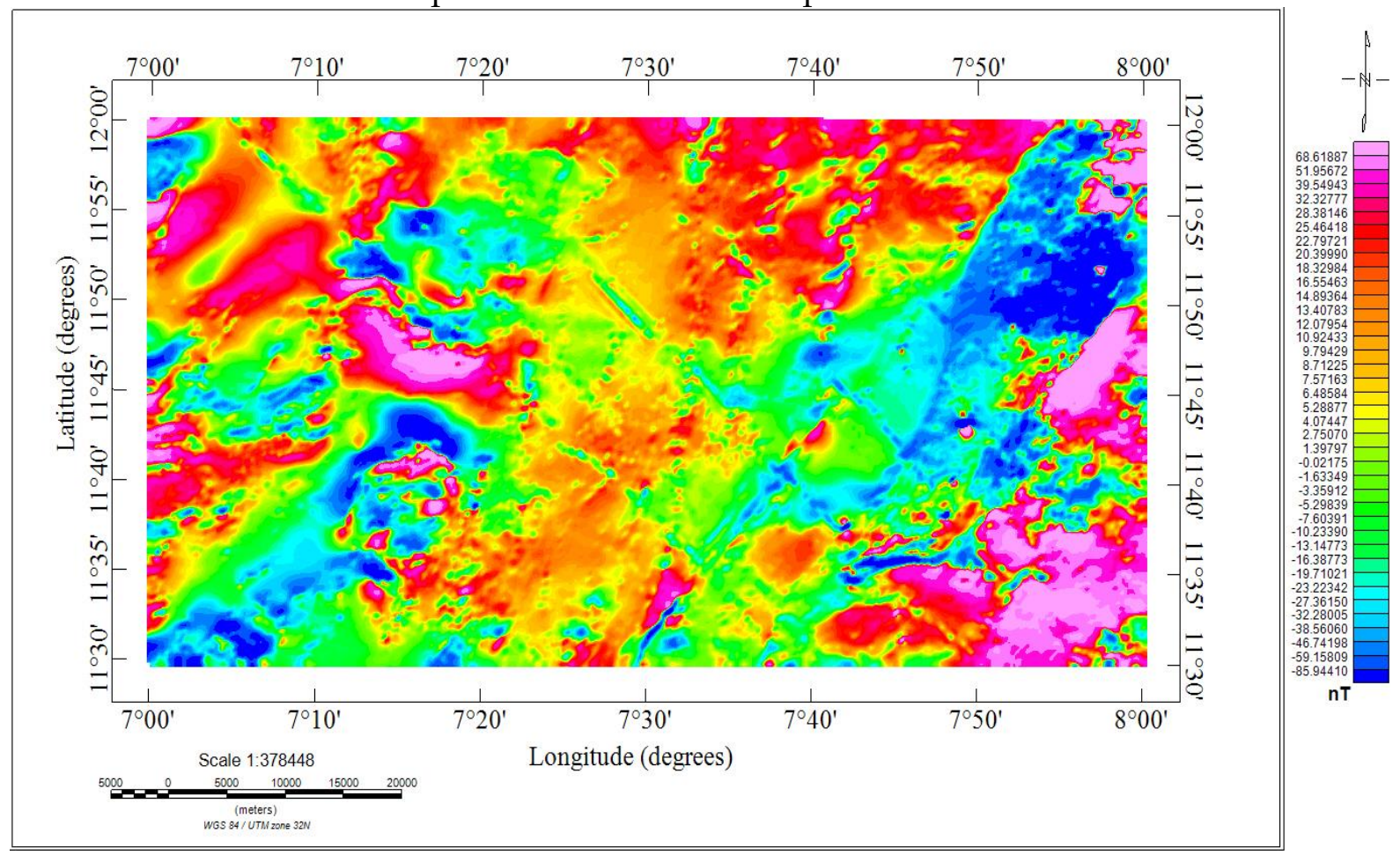

Figure 2: A map of the Reduction to Magnetic Pole of the Area of Study

Further processing and analysis were done on the RTP map using Oasis Montaj software to generate the lineament map from shaded relief image, this gives the structural complexity map detail of the area of study. As an enhancement technique on the RTP map, we can use either the space or frequency domain to determine the first vertical derivative or the second vertical derivative. In this research work, near surface features with its boundaries that defines a lineament were identified using the enhancement technique. In other words, short wave length anomalies are exposed at the expense of the longer wavelength anomalies due to combination of the vertical gradient and horizontal gradient of the magnetic anomaly (Ansari \&Alandar, 2009).

\section{Electrical Resistivity Tomography (ERT)}

The 2D electrical resistivity method can be applied in several problems like contaminant delineation, underground water detection, shallow subsurface structures investigations and mineral exploration (Van-Schoor, 2002). Its principle is generally based on the fact that properties of material (minerals, solid bedrocks and sediments) varies and hence creates electrical resistivity contrast between the material and the host medium (Panek et al., 2010). This principle is based on the fact that direct current is ejected into the earth through two electrodes (current electrodes) and the potential difference is measured through two electrodes (potential electrodes).

The 2D ERT survey was done using the dipole-dipole array type in the study because of its high resolution and sensitivity to horizontal property contrast with depth (Loke et al., (2003)). A total spread of $210 \mathrm{~m}$ by $20 \mathrm{~m}$ area was being covered. This data was collected using the tetrameter SAS 4000 with an electrode selector ES 464. The electrodes were laid out 
in a straight line (spread) with a $5 \mathrm{~m}$ spacing between electrodes to give a total spread length of $210 \mathrm{~m}$. Five parallel spreads running West-East direction were laid in the area of study. Usually, the field measurements are apparent values of resistivity from which an apparent resistivity pseudo section of the profile can be plotted. Further processing was done to edit or correct for noise values so as to obtain a good model that has a better continuous representation of the electrical resistivity distribution of the subsurface. The regularized least-squares optimization method was used for the inversion process in the RES2DINV software (de Groot Heldin \& Constable, 1990; Loke et al., 2003).

\section{RESULTS}

In the present study, aeromagnetic data was used to enhance and analyze subsurface structures that could be associated with Kaolin mineralization. This was subsequently followed up with the electrical resistivity tomography to further compliment the result.

The vertical derivative map (Figure 3 and 4), the analytical map (Figure 5) and the Euler map (Figure 6) are as shown below.
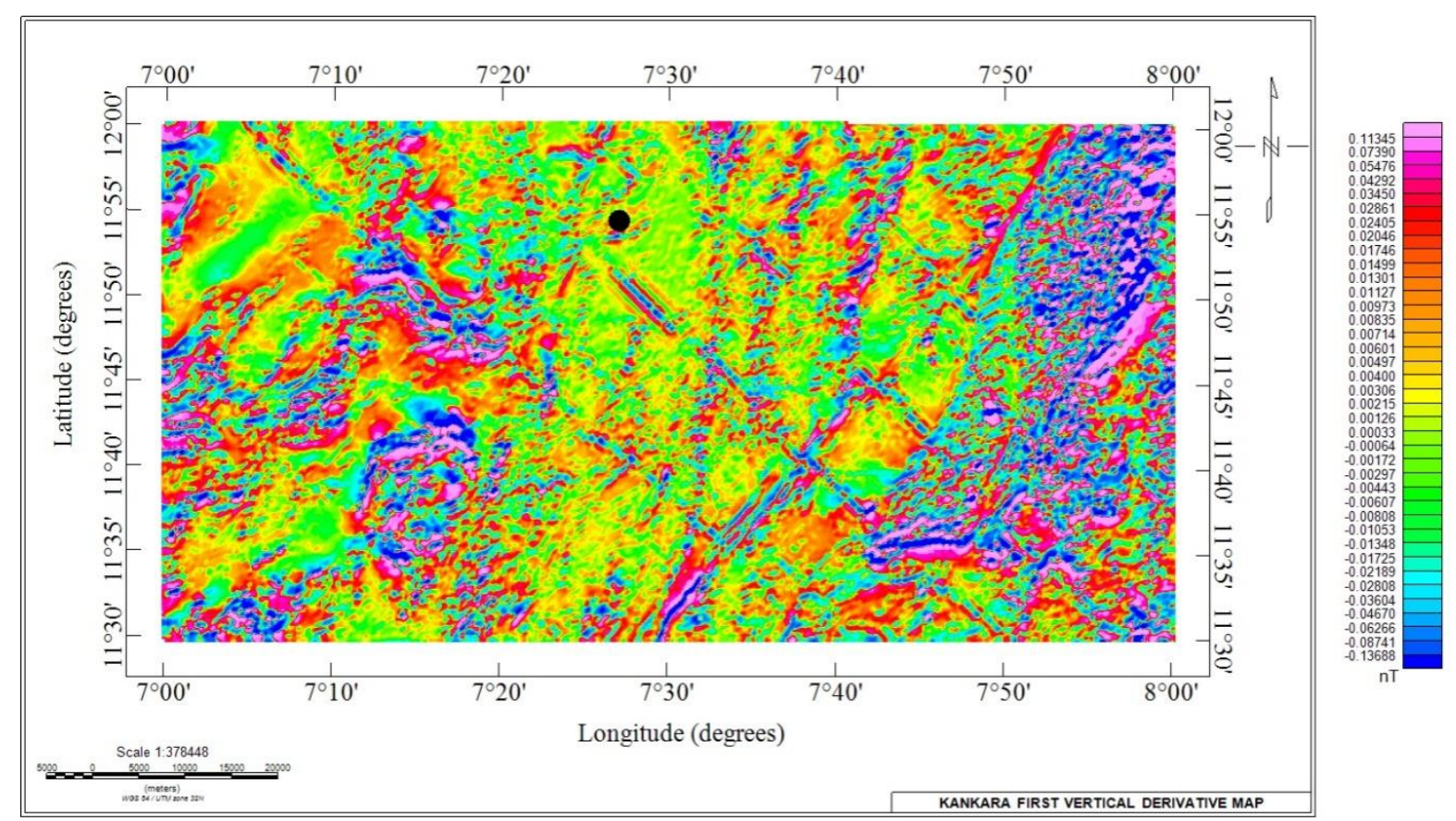

Figure 3: First Vertical Derivative map of the area of study (mining site at the dark spot) 


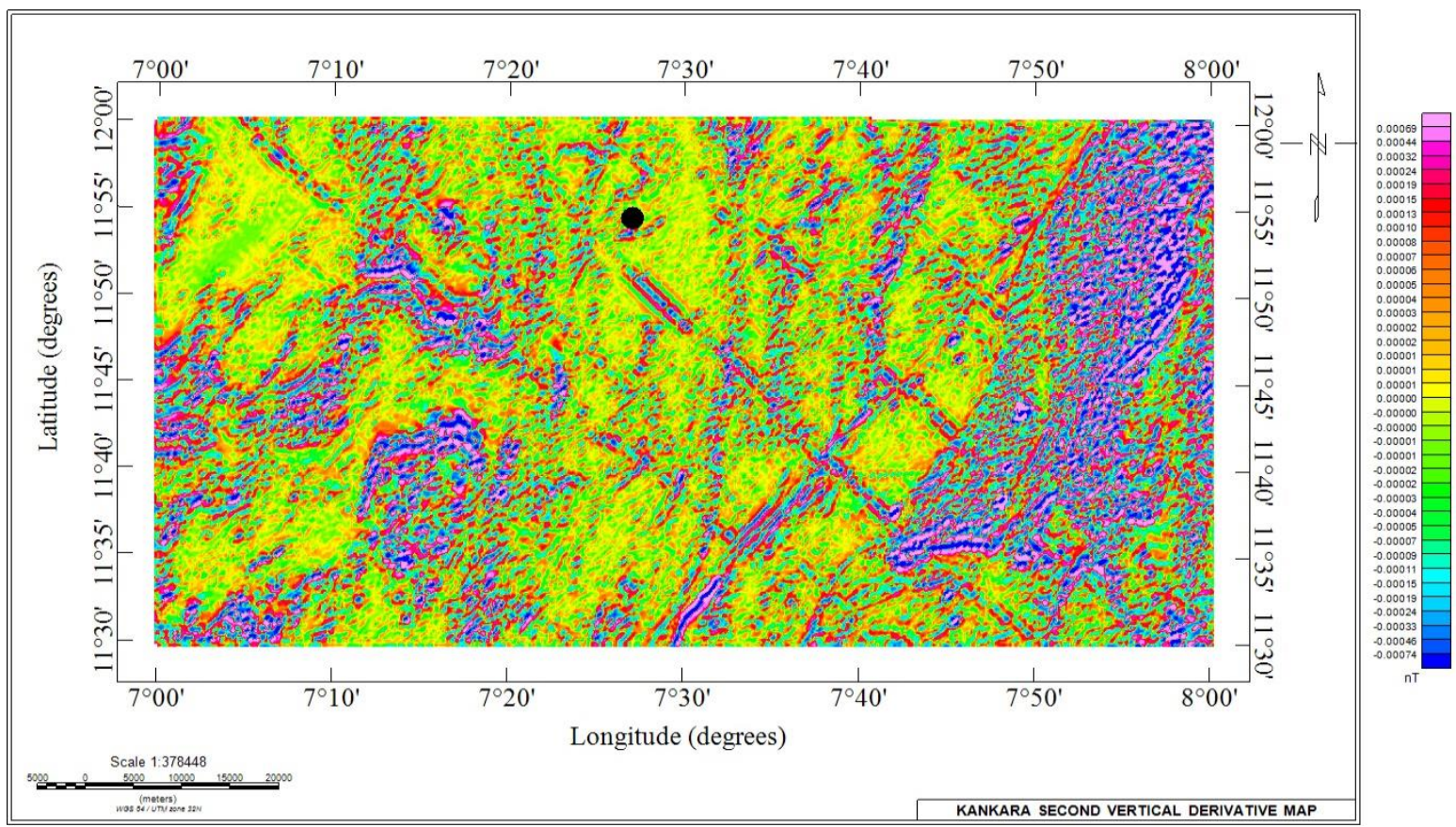

Figure 4: Second Vertical Derivative map of the area of study (mining site at the dark spot)

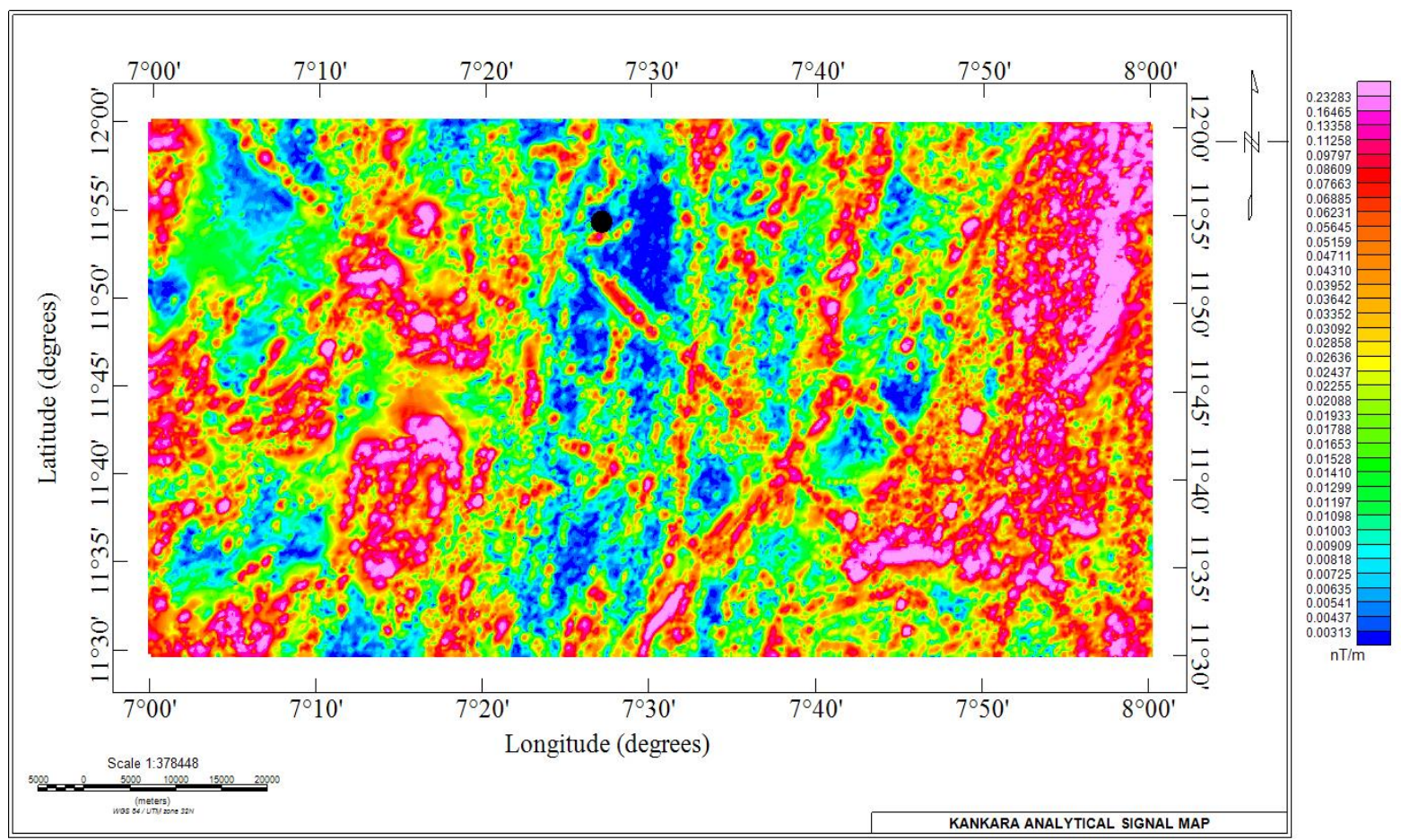

Figure 5: Analytical Signal Map of the area of study (mining site at the dark spot) 


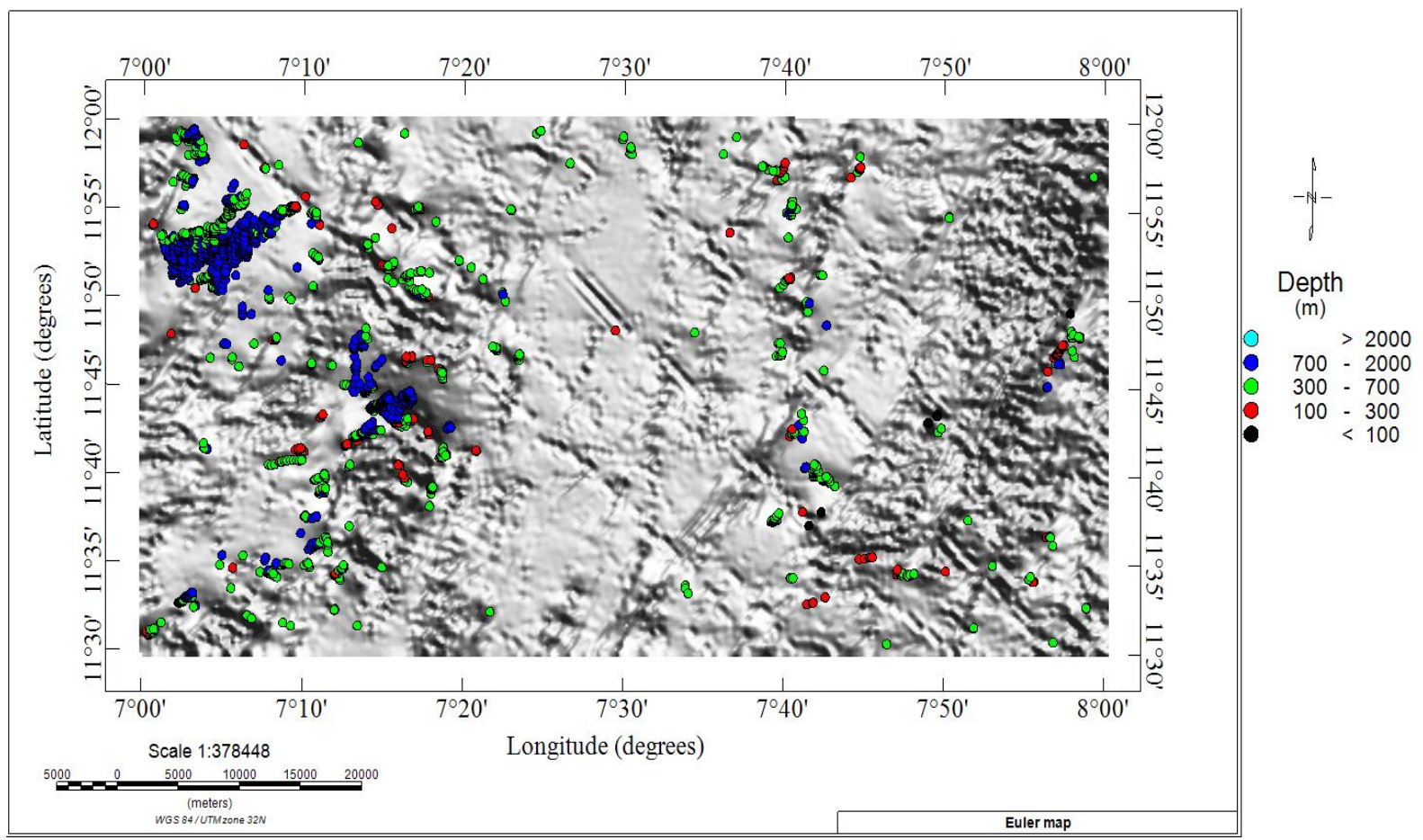

Figure 6: Depth solution for Euler deconvolution with structural index 1.0

Figures 7-11 shows the two-dimensional inversion result for all the profiles, with a $5.3 \%$ absolute root mean square (RMS) error for profile 1, $10.5 \%$ error for profile 2, $4.8 \%$ error for profile 3, $4.4 \%$ error for profile 4 and $4.2 \%$ error for profile five. Thus, this indicates a good fit has been achieved between the calculated and measured apparent resistivity values. The apparent resistivity results were correlated with lithology information obtained from borehole logs dug around the study area.

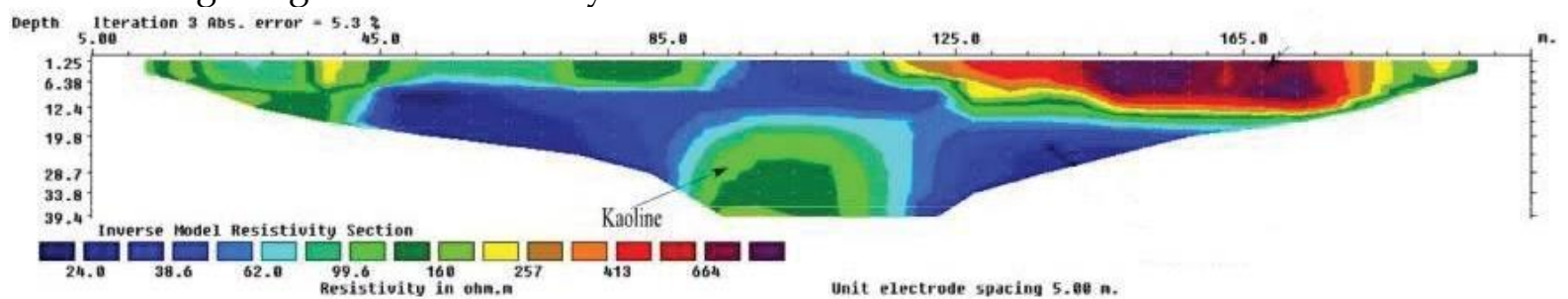

Figure 7: Profile one

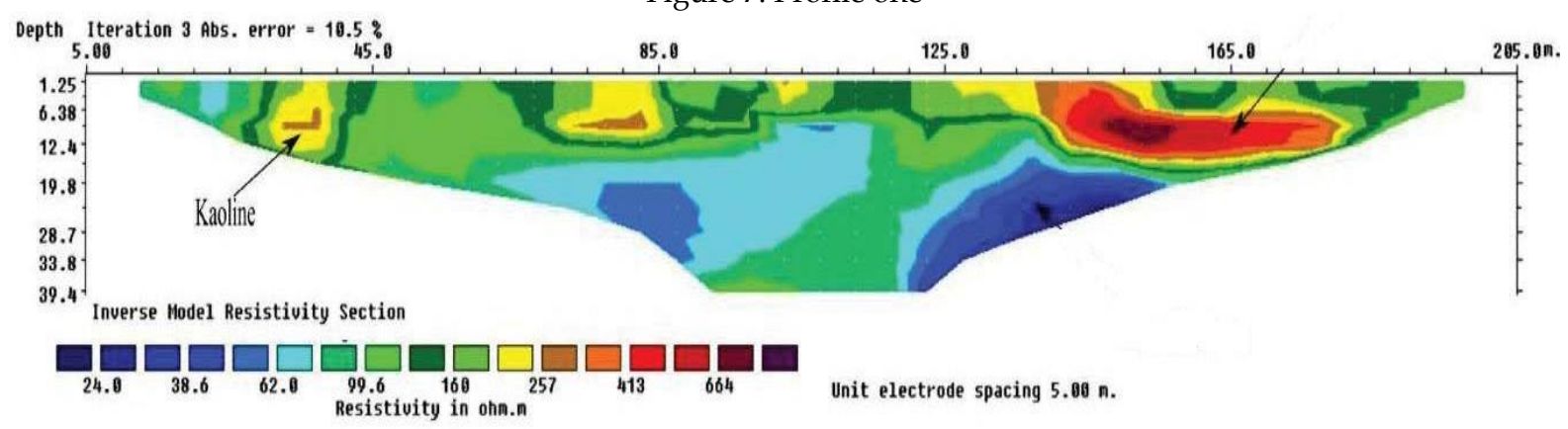

Figure 8: Profile two 


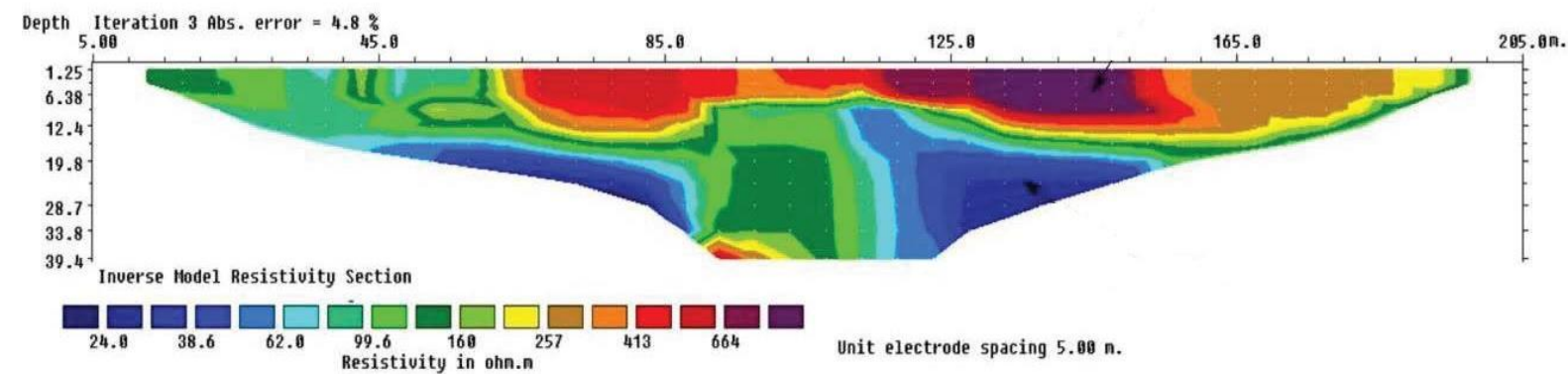

Figure 9: Profile three
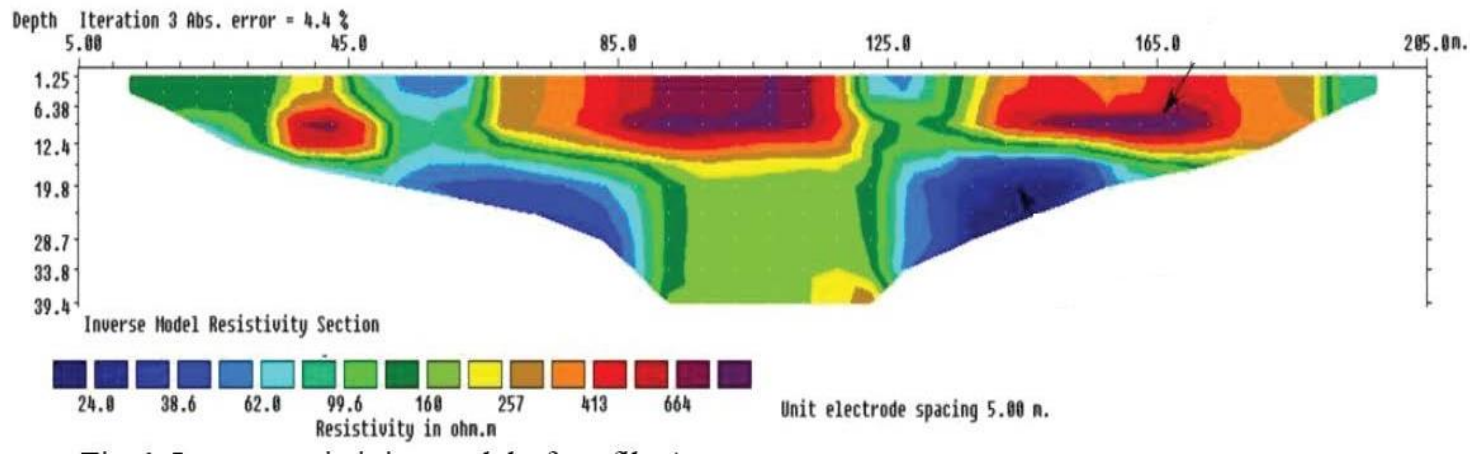

Figure 10: Profile four

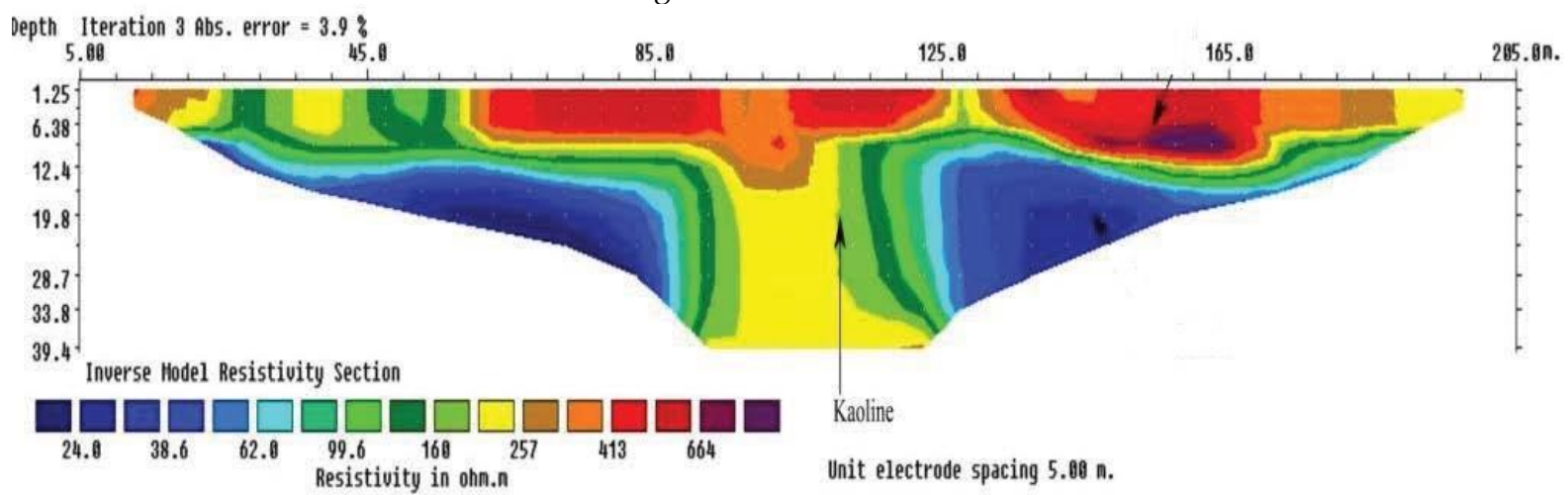

Figure 11: Profile five

\section{DISCUSSIONS}

According to previous literature (Ekosse, 2010), Kaolin deposits in Kankara area are products from granitoids and gneisses which contains large quantities of both mica and feldspars. Due to alteration, the muscovite rich (micas) and the microcline rich (feldspars) parent source rocks are eventually transformed to Kaolin in this area of study. This was used as a guide in delineating the Kaolin deposit within the surveyed area as presented in this article.

Considering the Aeromagnetic maps (Figures 3, and 4), shows that the vertical derivative map gave a better expression of the near surface anomalies (like faults) since this filter enhances such near surface anomaly (short wavelength) sources at the expense of the deepseated anomaly (long wavelength) sources. It is obvious that the short wavelength anomalies at shallow depths are predominantly at the Eastern part of the area of study while the long wavelength anomalies at larger depths are located towards the Western part (as shown in Figure 6) of the area of study due to the presence of sedimentary cover as supported by the works of Olomo et al., (2018).

A glance at the maps (Figures 3, 4, 5 and 6) shows that the Northwest - Southeast trend are most obvious in the area of study with some less prominent in the Northeast - Southwest 
trend. However, there are little structures trending in the East - West and the North - South directions. This trend seems to correlated with the location of the Kaolin mining site, where the electrical resistivity tomography survey was done.

The analytical signal map (Figure 5) shows the various distribution of magnetic susceptibility of rocks in the area of study which has highlighted the discontinuities of subsurface anomalies patterns. A comparison with the First Vertical Derivative map (Figure 3), has shown complex differentiations based on mineralogical texture (compositions) and depth of emplacement. As a result, highly rich ferromagnesian-bearing rocks with traces of felsic minerals are associated with the high magnetic anomalies zones. Obviously, the Analytical Signal map has distinguished three different magnetic zones. Firstly, the high magnetic anomalies zones (HM) 0.23283-0.02437 nT/km (purple to yellow colour) are related to gabbroic rocks, ophiolitic metagabbro, dokhan volcanic, hammamat felsite and ophiolitic serpentine because these rock type has large amount of felsic minerals and highly ferromagnesian. Secondly, the moderate zone (MM) with gradient $0.02255-0.01003 \mathrm{nT} / \mathrm{km}$ associated with gneiss - granite as these rocks contain low amount of felsic minerals and are highly ferromagnesian. Thirdly, the Low to fairly low magnetic zone (LM) with a gradient 0.00909-0.00313 nT/ km are associated with; metasediments, hammamatclastics, metavolcanic, granite, and clastic sediments because these rocks contain more than $60 \%$ quartz. According to Akinlalu, et al., (2018), the depth to magnetic basement can be estimated as the Euler depth for the deepest source in this area of study of Kankara region. The mineralization zones are identified at the shallow source depths., and these anomalies controlled structurally by the obvious major Northeast - Southwest and Northwest Southeast trends with minor traces of the East - West and North - South trends. This supports the appreciable effect of the Pan African Orogeny (Akinlalu, et al., (2018)).

Considering the ERT results, the distribution of the subsurface resistivity in the inversion model showed a wide variation in the soil resistivity and at different depth along each profile.

The resistivity of the three layers top, weathered and fresh basement, just as was obtained in Hussaini et al., 2015, revealed the top layer to be characterized by its high resistivity across the survey area with the resistivity values ranges between 5-550 $\Omega \mathrm{m}$ with thickness varying from 1.25-39.4 m. The variations in the resistivity values represent inhomogeneity nature of the layer. The subsurface heterogeneity comes from the presence of top soil, sandy clay, saturated sandy clay, Kaolin, clay and lateritic clay. Consequently, these results depict the range of resistivity values of Kaolin within the survey area between 41-97 $\Omega \mathrm{m}$ having thickness ranging from 1.25-39.4 m. The intermediate layer, which is the soft weathered basement rock, composed of feldspar, quartz and biotite-mica characterized with resistivity values ranging from 56-1238 $\Omega \mathrm{m}$ having thickness vary from a depth of $14 \mathrm{~m}$ to $39.4 \mathrm{~m}$. The fresh basement underlies the soft weathered basement rock with resistivity values ranging between $200-5129 \Omega \mathrm{m}$ and above, from a depth of about $34 \mathrm{~m}$.

\section{CONCLUSION}

This study has shown how useful the aeromagnetic and electrical resistivity survey can be used for the delineation of faults associated with mineralization. It has shown that majority of the fault zone trends Northeast - Southwest and Northwest - Southeast direction with few traces in the East - West and North - South directions. The mining site lies along this fault line, and the electrical resistivity survey was carried out on the site, which gave a lithological structure of the rock bearing minerals, based on the resistivity contrast with the host rocks. This gives three distinct geological layers of Top soil, weathered basement and 
fresh basement. It revealed that the Kaolin mineral lies within the weathered basement, at depths approximately $10-15 \mathrm{~m}$.

\section{REFERENCES}

Ajayi, O. A and Adefila, S. S., (2012). Comparative Study of Chemical and Biological Methods of Beneficiation of Kankara Kaolin, International Journal of Scientific and Technology Research, 8(1):13-18.

Ajibade, O.C. (1976). Provisional classification and correlation of the schist belt in Northwestern Nigeria. Geology of Nigeria, Kogbe (ed.) Elizabethan publishing company, Lagos. Nigeria, pp. 85-90.

Aliyu, K. I. and Ado, I. M., (2020). Mapping Geology and Structural Features of Kazaure SE, NW Nigeria: Justifying Groundwater Potential Model. Researches Reviews of the Department of Geography, Tourism and Hotel Management, 49(1): 1-21.

Anka, S.A., Sanda, A., Bello, T.S., Waziri, A.F., Muhammad, A.S., Bello, I., and Nasiru, A.M. (2020). Environmental Effect of Lead Contamination on Mining Communities in Zamfara State, Nigeria: A Review, Journal of Biology \& Todays World, 9(9):1-3.

Ansari, A.H., Alamdar, K., (2009). Reduction to the pole of magnetic anomalies using analytic signal. World Appl. Sci. J., 7:405-409.

Badmus, B. S. and Olatinsu, O. B., (2009). Geophysical evaluation and chemical analysis of Kaolin clay deposit of Lakiri village, southwestern Nigeria, International Journal of Physical Sciences, 4 (10):592-606.

Christian, Z. C., John, A.P. and Shehu, Z. (2018). Chemical investigation of Kankara Kaolin for its pharmaceutical applications, Open Access J. Trans Med Res., 2(1):11-13.

Cooper, G.R.J., and Cowan D.R. (2008). Enhancing potential field data using filters on the local phase, Computers and Geosciences 32:1585 - 1591.

deGroot-Hedlin, C. and S.C. Constable, (1990). Occam's inversion to generate smooth, two dimensional models from magnetotelluric data, Geophysics, 55:1613-1624. DOI:10.1190/1.1442813.

Ekosse, G.E. (2010). Kaolin deposits and occurrences in Africa: Geology, mineralogy and utilization, Applied Clay Science, 50:212-236.

Hussaini, A., Sule, P.O., Osumeje, J.O., Daniel, E., Zainab, M. (2016). Two-Dimensional Electrical Resistivity Imaging Applied to The Delineation of Kaolin Deposit at Dajin Gwamna, Katsina State, Northwestern Nigeria, Nigerian Journal of Scientific Research, 15(2): $234-244$.

Jongmans, D., Garambois, S., (2007). Geophysical investigation of landslides: A review, Bulletin de la Société Géologique de France, 178(2):101-112.

Kankara, I. A. and Farouk, H. A. (2015). Provisional dating of metasedimentary rock in South Katsina State, Northwestern Nigeria. Studies in Proterozoic Crustal Evolution. Journal of Physical Science and Environmental Studies, 1(4):55- 61.

Lebourg, T., Binet, S., Tric, E., Jomard, H., El Bedoui, S., (2005). Geophysical survey to estimate 3D sliding surface and the $4 \mathrm{D}$ evolution of the water pressure on part of a deep-seated landslide. Terra Nova 17:399-406.

Loke, M.H., I. Acworth and T. Dahlin, (2003). A comparison of smooth and blocky inversion methods in 2D electrical imaging surveys. Exploration Geophysics, 34:182-187.

Méric, O., Garambois, D., Jongmans, M., Wathelet, M., Chatelain, J., Vengeon, J., (2005). Application of geophysical methods for the investigation of the large gravitational mass movement of Séchilienne, France. Canadian Geotechnical Journal 42:1105-1115.

Miller, H.G., and Singh, V. (1994). Potential field tilt - a new concept for location of potential field sources. Journal of Applied Geophysics 32:213-217.

Nwabueze, I. E. (2018). Lead (pb) mining in Ebonyi state, Nigeria: implications for 
environmental and human health risk, International Journal of Environment and Pollution Research, 6(1): 24-32.

Olade, M. A. (2019). Solid Mineral deposits and mining in Nigeria: A sector in transitional change, Achievers Journal of Scientific Research, 2(1):1-15.

Olomo, K. O., Olayanju, G. M., Adiat K. A. N., Akinlalu, A. A. (2018). Integrated Approach Involving Aeromagnetic and Landsat for Delineating Structures and Its Implication on Mineralization, International Journal of Scientific and Technology Research, 7(2): 208217.

Oyeka, A.N. (1976). Report on Kankara Kaolin deposits, Kankara, Katsina province, North central State with notes on Marble occurrence. Geological Survey Nigeria, unpublished Report No. 1529.

Pánek, T., Margielewski, W., Táborík, P., Urban, J., Hradecký, J., Szura, C., (2010). Gravitationally induced caves and other discontinuities detected by 2D electrical resistivity tomography: case studies from the Polish Flysch Carpathians, Geomorphology, 123:165-180.

Van Schoor, M., 2002. Detecting of sinkholes using 2D electrical resistivity imaging. Journal of Applied Geophysics 50:393-399.

Wagner, M. and Wellmer, F.W. (2008). Global mineral resources: occurrence and distribution. Environmental and Engineering Geology, Vol. 3 UNESCO-EOLSS Report, pp 26.

Wijns, C., Perez, C., Kowalczyk, P., 2005. Theta map: edge detection in magnetic data.

Geophysics, 70 (4): L39-L43. 